\title{
EFFECT OF STOCKING DENSITY AND DIET'S TYPE ON PRODUCTIVE PERFORMANCE AND ECONOMIC EFFICIENCY OF AFRICAN CATFISH Clarias gariepinus UNDER SEMI-INTENSIVE SYSTEM
}

\author{
R. M. Abou-Zied \\ Animal Production Department, Faculty of Agriculture, Fayoum University, Egypt \\ Corresponding author: abouzied2004@yahoo.com
}

\section{SUMMARY}

Two experiments were conducted to evaluate the optimum stocking density and diet's type recently used in catfish farms, on both growth performance and economic efficiency of African catfish Clarias gariepinus. The first experiment tested three different stocking density of catfish with average weight of $46.83 \mathrm{~g} \pm 1.62$ at a rate of 4,8 and $12 \mathrm{catfish} / \mathrm{m}^{3}\left(T_{1}, T_{2}\right.$ and $\left.T_{3}\right)$ in hapas $(4 \times 6 \times 0.80$ (in depth) $\mathrm{m}$ ). The experiment started on 24 may, 2014 and continued for 186 days. The results showed that the low stocking $T_{1}$ was the best in both growth performance and economic efficiency. The second experiment was conducted in earthen ponds using catfish with average body weight of $56.5 \pm 1.05 \mathrm{~g}$ to evaluate three types of diets: poultry slaughters wastes (offal and dead chicken) PO, food factories wastes (FF) and artificial feed (AF). The experiment started on 15 May, 2014 and continued for 210 days. The results indicated that $P O$ and FF diets were better than AF for economic efficiency and the treatment of PO diet was the best in all treatments in growth performance and economic efficiency.

In conclusion, catfish can be cultured under high stocking density $\left(T_{3}\right)$ without causing any problems and the low stocking $T_{1}$ was the best in both growth performance and economic efficiency in semi-intensive at earthen ponds system. In addition, using non-traditional diets of poultry slaughter wastes (PO) and wastes of food factory $(F F)$ could be used to reduce the costs of production.

\section{Keywords: African catfish Clarias gariepinus, poultry offal diet, factory by products and stocking density}

\section{INTRODUCTION}

Recently, African catfish, Clarias gariepinus is generally considered to be one of the most important tropical fresh water fish species for aquaculture (Dada and Wonah, 2003), and is considered as valuable species not only in Egypt, but also in many other parts of the world because of their high growth rates, tolerance of a wide range of temperature and dissolved oxygen levels. Catfish is considered an important and desirable commercial species worldwide because of its good palatability and high fecundity (Hecht et al., 1996; Rad et al., 2003; Soltan and Tharwat, 2006 and Amisah et al., 2009).

In the last few years catfish farming spread in Fayoum governorate, Egypt as a result of low cost of feeding by using unconventional materials and fish stocking density of 4-6 tons/feddan (30-50 thousand catfish/feddan). Catfish production in Egypt reached 48,750 ton which representing about $3.55 \%$ of the total fish production (GAFRD, 2012).

Stocking density is one of the main factors determining fish growth (Engle and Valderrama, 2001 and Rahman et al., 2005) and the final biomass harvested (Boujard et al., 2002). Limiting the optimum stocking density for any species is a critical factor not only for designing an efficient culture system (Leatherl and Cho, 1985) but also for optimum husbandry practices. Controlling the fish size and production are the two important tasks to meet the market demands (Aksungur et al. 2007).
The effects of stocking density on growth and survival have been studied on some African catfishes (Haylor, 1992; Ewa-Oboho and Enyenihi, 1999; Coulibaly et al., 2007; Jamabo and Keremah 2009; Edward et al., 2010 and Dasuki et al., 2013). However, maximum stocking density is limited by the biology of the organisms (Hecht and Pienaar, 1993; Baras and Joblin, 2002). High densities can intensify stress which may lead to an increase in fish diseases. In some species, increasing stocking density usually results in stress conditions, such as aggressive behavior and dominance which leads to enhancing energy requirements resulting in reduced growth, food utilization and net yield (Begout-Anras and Lagardère, 2004).

Fish feed products are mostly based on ingredients derived from crop residues. On the other hand, vast resources of slaughterhouse /poultry /silkworm by-products, which are termed as wastes and are rich in proteins and minerals, are freely available in most of the countries. Utilization of these so called waste materials in the production of fish feeds will not only solve the problem of nutritional needs of fish but also help in reducing environmental pollution caused by the discarded animal tissues scattered all over the rural as well as urban areas leading to public nuisance and vector breeding centers. Poultry by-product meals (PBM) are valuable alternative protein sources for carnivorous fish and have been tested in diets for channel catfish (Lochmann and Phillips, 1995 and Gomaah, 2006). 
Animal by-products such as meat, bone meal and poultry by-product meal have considerable potential as feed ingredients in fish production systems (Fasakin et al., 2005 and Wei et al., 2006) and were comparatively less expensive than fish meal (AbdelWarith et al., 2001). These animal protein ingredients are good sources of amino acids with high protein content, total digestible dry matter and energy similar to fish meal (Bureau et al., 2000). Therefore, poultry by-product meal is considered a probable replacement for fish meal (Muzinic et al., 2006 and Rawles et al., 2006).

Poultry offal, a by-product of the broiler processing plant and processors in local markets is sufficiently available to be recycled as animal protein source for use in fish feeds. In addition, Faturoti (2000) reported that local chicken offal (cooked and dried) contained $61.6 \%$ crude protein (CP), $16.5 \%$ crude lipid, 3.5\%crude fiber, $9.0 \%$ ash and $8.3 \%$ moisture. Faturoti (2000) in a growth response studies observed best gross profit and profit index at $75 \%$ and $100 \%$ inclusions of chicken offal in the diet of Clarias gariepinus.

Therefore, the present study aimed to discuss the possibility of use high stocking density in culture with maintaining a non-significant impact on the growth and the lack of problems in semi intensive farming in ponds with a lack of water change and also comparison between unconventional feed (poultry slaughters wastes and food factory wastes) and conventional feed (artificial feed) which is used commercially in most farms for economic efficiency of farmed African catfish.

\section{MATERIALS AND METHODS}

Two trials were conducted to evaluate the effect of stocking density and diet's type recently used commercially in catfish farms on both growth performance and economic efficiency of African catfish Clarias gariepinus under semi-intensive system. The first experiment was conducted to evaluate the effect of different stocking densities (4, 8 and 12 catfish $/ \mathrm{m}^{3} \mathrm{~T}_{1}, \mathrm{~T}_{2}$ and $\mathrm{T}_{3}$ ) on both growth performance and economic efficiency at fish farm in Faculty of Agriculture, Fayoum University, Egypt, in hapas experimental unit $(4 \times 6 \times 0.80 \mathrm{~m})$ under semi intensive system. The experiment started on 24 May, 2014 and continued for 186 days with catfish of an initial weight was $46.83 \pm 1.62 \mathrm{~g}$. Each of the treatments was replicated twice. Fish were fed twice daily an artificial floating feed containing $27.1 \%$ crude protein five days a week at $3 \%$ of total biomass per treatment for the first three months, then $1 \%$ for the remaining culture months. Sampling of fish was taking monthly, early in the morning to determine new weight and adjusted feed quantity.

The second experiment was conducted to evaluate effects of three types of diets; poultry slaughters wastes (offal and chicken dead) PO, wastes of food factories (FF) and artificial feed (AF) on both growth performance and economic efficiency of African catfish in six earthen pond in commercial fish farm in Sakshouk village, Fayoum governorate, Egypt. Each treatment had two replicates, the fish of an initial weight of $56.5 \pm 1.05 \mathrm{~g}$ and stocked at a rate of 16000 /pond. This experiment started on 15 May, 2014 and continued for 210 days. Catfish feed a diet, at a rate of $3 \%$ of total fish biomass for first three months and then was decreased to $1 \%$ until experiment ended, twice daily every day except Friday as follows: First diet (PO) fed moist. The second diet (AF) from El-Baraka factory and the third diet (FF) mixture wastes of biscuits, pasta and beans break factories. Water was exchanged every two days at a rate of 0.3 of total water pond. At the end of the experiment growth and economic parameters were determined.

\section{Parameters measurements:}

At the end of the experiment, growth parameters and survival rate were measured as follows:

- Weight gain $=$ Final weight - Initial weight (Effiong et al., 2009).

- Daily gain = Weight gain, $\mathrm{g} /$ period in days. (Effiong et al., 2009).

- Specific growth rate (SGR,\%) = 100 (ln Final weight-ln Initial weight)/period in days, where $\ln$ is the natural log. (Effiong et al., 2009).

- Feed conversion ratio $($ FCR $)=$ feed offered / weight gain (Effiong et al., 2009).

- Survival rate (SR) \%= Final number of fish /Initial number of fish $\times 100$.(Charo-Karisa et al., 2006).

- Profit index $(P I)=$ value of fish produced/total costs (Abu et al., 2010)

\section{Chemical analysis:}

The used diets and fish were analyzed for their proximate composition in triplicates following the methods described by AOAC (2000).

\section{Water quality measurement:}

Water temperature, $\mathrm{pH}$, dissolved oxygen (DO), ammonia nitrogen $\left(\mathrm{NH}_{3}-\mathrm{N}\right)$, nitrate and salinity throughout the experimental period were measured periodically every week in the morning and at noon by centigrade thermometer, Orion digital $\mathrm{pH}$ meter model 201, oxygen meter, Cole Parmer model 5946, $\mathrm{HACH}$ test kit ammonia mid-range $0-3 \mathrm{mg} / \mathrm{L}$ model NI-8 , HACH test kit Nitrate/Nitrite model NI-12 and TDS apparatus, respectively for both experiments

\section{Statistical Analysis:}

Statistical analyses were performed using SPSS (2007), one way analysis of variance was used. Significance among treatments was evaluated at the 5 $\%$ probability level using Duncan (1955).

At the end of each experiment, the pond was drained and the fish were harvested and weighed. The cost-benefit analysis was carried according to current local market prices of African catfish in Egyptian L.E. 


\section{RESULTS AND DISCUSSION}

Experiment 1:

\section{Water quality:}

Water quality parameters during the present study were within the suitable ranges for catfish culture (Boyd and Litchtkoppler, 1979; Viveen et al., 1985, Auta, 1993 and Adakole, 2000) and are presented in
Table (1). Water temperature ranged from 22 to 30 ${ }^{\circ} \mathrm{C}$ with an average of $\left(28^{\circ} \mathrm{C}\right)$, dissolved oxygen ranged from 5.5 to $6.3 \mathrm{mg} / \mathrm{L}$, with an average of $(6.02 \mathrm{mg} / \mathrm{L})$, water $\mathrm{pH}$ ranged from 7.90 to 8.05 , with an average of (7.97). Ammonia concentration was not detected. Salinity was almost stable.

Table 1. Mean $( \pm$ SE) of water quality parameters of hapas stocked with different densities of African catfish during the first experiment

\begin{tabular}{lcccccc}
\hline Months & $\begin{array}{c}\text { Temp., } \\
{ }^{\circ} \mathbf{C}\end{array}$ & $\begin{array}{c}\mathbf{D O}, \\
\mathbf{m g} / \mathbf{L}\end{array}$ & $\mathbf{p H}$ & $\begin{array}{c}\mathbf{N H}_{\mathbf{3}} \mathbf{- H}, \\
\mathbf{m g} / \mathbf{L}\end{array}$ & $\begin{array}{c}\mathbf{N O}_{\mathbf{3}} \\
\mathbf{m g} / \mathbf{L}\end{array}$ & $\begin{array}{c}\text { Salinity, } \\
\text { \%o }\end{array}$ \\
\hline June & $28 \pm 0.80$ & $6.3 \pm 0.29$ & $7.95 \pm 0.21$ & 0 & 0 & 0.3 \\
July & $30 \pm 0.82$ & $6.2 \pm 0.29$ & $7.90 \pm 0.20$ & 0 & 0 & 0.3 \\
August & $30 \pm 0.81$ & $5.9 \pm 0.28$ & $7.95 \pm 0.22$ & 0 & 0 & 0.3 \\
September & $28 \pm 0.80$ & $5.9 \pm 0.28$ & $7.95 \pm 0.21$ & 0 & 0 & 0.3 \\
October & $27 \pm 0.79$ & $5.8 \pm 0.27$ & $8.00 \pm 0.22$ & 0 & 0 & 0.3 \\
November & $25 \pm 0.78$ & $6.0 \pm 0.28$ & $8.05 \pm 0.23$ & 0 & 0 & 0.3 \\
Average & $28 \pm 0.80$ & $6.02 \pm 0.29$ & $7.97 \pm 0.21$ & 0 & 0 & 0.3 \\
\hline
\end{tabular}

\section{Effect of stocking density on growth performance:}

The studied growth parameters in first experiment are presented in Table (2). Final mean body weight, weight gain, average daily gain and specific growth rate (SGR) were decreased with increasing stocking density. There were significant differences in these parameters among densities of 4,8 and $12 \mathrm{catfish} / \mathrm{m}^{3}$. African catfish stocking at low density recorded the highest final weight, weight gain, average daily gain, SGR and survival being $875 \mathrm{~g} /$ fish, $826 \mathrm{~g} /$ fish, 4.44 $\mathrm{g} /$ day and $1.55 \% /$ day, respectively. However, the stocking density $12 \mathrm{fish} / \mathrm{m}^{3}$ had the lowest estimates (595, 546, 2.94 and 1.34, respectively). Survival rate was not significant but was better at the low density than the high density. The high survival rate recorded in all the treatments could be partially attributed to the physico-chemical parameters of the water and also due to the good health condition of the fish. The survival of catfish ranged between $97.08-98.75 \%$ which was comparable to similar work that was done by Osofero et al. (2007) and Dasuki et al. (2013). Low mortality $(2.92 \%)$ which was recorded in this study seemed to be an indication of proper handling of experimental procedures or the high tolerance of the fish handling.

In fact, under crowded conditions at higher stocking densities, fish suffer stress as result of aggressive feeding interaction and eating less resulting in growth retardation (Bjoernsson, 1994). Stocking density has been considered to be chronically stressful to the reared animals (Sugunan and Katiha, 2004). Several studies have also demonstrated that increased stocking density has a negative effect on survival rate and growth (Rowland et al., 2004) as well as Ellis et al. (2002) reported that, Rainbow trout growth and feeding ratio was better at low stocking density compared to the growth and feeding ratio of fish at higher stocking density in our trial. High stocking density led to increase activity (air breathing, swimming), decrease aggression and high density can be negatively affected water quality according to Diana and Fast (1989) and higher stocking density often resulted in higher ammonia concentrations

Table 2. Effect of different stocking densities on growth performance of African catfish under semi intensive system $($ Mean \pm S.E)

\begin{tabular}{lcccc}
\hline \multicolumn{1}{c}{ Items } & \multicolumn{2}{c}{ Treatments } & \multicolumn{2}{c}{ SED $^{* *}$} \\
\hline Initial mean body weight, $\mathbf{g}$ & $\mathbf{T}_{\mathbf{1}}$ & $\mathbf{T}_{\mathbf{2}}$ & $\mathbf{T}_{\mathbf{3}}$ & 4.74 \\
Final mean body weight, $\mathbf{g}$ & $49.00^{\mathrm{a}} \pm 2.0$ & $42.50^{\mathrm{a}} \pm 2.5$ & $49.00^{\mathrm{a}} \pm 1.0$ & 55.68 \\
Weight gain, g & $875^{\mathrm{a}} \pm 25.0$ & $710^{\mathrm{b}} \pm 30.0$ & $595^{\mathrm{c}} \pm 5.0$ & 55.16 \\
Average daily gain, $\mathbf{g}$ & $826^{\mathrm{a}} \pm 27.0$ & $667.5^{\mathrm{b}} \pm 27.5$ & $546^{\mathrm{c}} \pm 6.0$ & 0.30 \\
SGR, \% /day & $4.44^{\mathrm{a}} \pm 0.15$ & $3.59^{\mathrm{b}} \pm 0.15$ & $2.94^{\mathrm{c}} \pm 0.03$ & 0.05 \\
Survival rate\% & $1.55^{\mathrm{a}} \pm 0.04$ & $1.51^{\mathrm{a}} \pm 0.01$ & $1.34^{\mathrm{b}} \pm 0.02$ & 0.02 \\
\hline
\end{tabular}

* Average in the same row having different superscripts significantly different at $(\mathrm{P} \leq 0.05)$.

** SED, standard error of a difference between two means

\section{Effect of stocking density on feed utilization:}

As shown in Table (3) feed intake, FCR, PER, PPV and EPV\% had significant differences. The $\mathrm{T}_{1}$ had the highest feed intake, PER, PPV\% and EPV\% but better FCR than other treatments $(1465,2.06$, 34.12 and 0.21 , respectively). Whereas, the $\mathrm{T}_{3}$ had the lowest FI and poor FCR, PER, EER and EPV\% $(1045,1.91,1.91,30.87,0.12$ and 0.19 , respectively. 
Table 3. Effect of different stocking densities on feed utilization of African catfish through under semi intensive system (Mean \pm S.E)

\begin{tabular}{lcccc}
\hline \multirow{2}{*}{ Items } & \multicolumn{3}{c}{ Treatments } & \multirow{2}{*}{ SED ** $^{*}$} \\
\cline { 2 - 5 } Feed intake, g/fish & $\mathbf{T}_{\mathbf{1}}$ & $\mathbf{T}_{\mathbf{2}}$ & $\mathbf{T}_{\mathbf{3}}$ & \\
FCR & $1465^{\mathrm{a}} \pm 35$ & $1255^{\mathrm{b}} \pm 45$ & $1045^{\mathrm{c}} 2.0$ & 80.62 \\
PER & $1.77^{\mathrm{b}} \pm 0.015$ & $1.88^{\mathrm{a}} \pm 0.010$ & $1.91^{\mathrm{a}} \pm 0.021$ & 0.04 \\
PPV\% & $2.06^{\mathrm{a}} \pm 0.018$ & $1.95^{\mathrm{b}} \pm 0.010$ & $1.91^{\mathrm{b}} \pm 0.021$ & 0.04 \\
EER & $34.12^{\mathrm{a}} \pm 0.24$ & $33.32^{\mathrm{a}} \pm 0.23$ & $30.87^{\mathrm{b}} \pm 0.34$ & 0.68 \\
EPV\% & $0.12^{\mathrm{a}} \pm 0.001$ & $0.12^{\mathrm{a}} \pm 0.0008$ & $0.12^{\mathrm{a}} \pm 0.0001$ & 0.01 \\
\end{tabular}

* Average in the same row having different superscripts significantly different at $(\mathrm{P} \leq 0.05)$.

** SED, standard error of a difference between two means

In the present study, FCR was significantly influenced by increasing stocking density of African catfish. This was in agreement with other reports using African catfish as well as in other species (Cruz and Ridha, 1989 and Almazán-Rueda, 2004). This is in agreement with El-Sayed (2002) who reported a negative correlation between growth and feed efficiency in Nile tilapia stocked at various densities. In addition, Lambert and Dutil (2001) found a negative effect of an increased stocking density of Cod Gadus morhus on the condition index and postulated decreased food intake as the cause. A decreased food intake is often associated with increased stress and the food conversion ratio is decreased with increasing stocking density. However, Watanabe et al. (1990) reported that feed conversion of Florida red tilapia fed supplementary feed did not differ at densities ranging from 100 to $300 / \mathrm{m}^{3}$.

The reduction in FCR with increasing density can be attributed to the feeding behavior of catfish (Almazán-Rueda, 2004). However, Hecht et al. (1997) reported that at high density, African catfish react faster to the presence of food and consumed a meal much faster than at low density. Hecht and Uys (1997) also found that the time it took for fish to respond to food and to consume a meal was decreased with increasing density. In addition,
Papoutsoglou et al. (1998) found that the feed efficiency ameliorated in faster growing fish, while El-Sayed (2002) reported a negative correlation between growth and feed efficiency in Nile tilapia stocked at various densities.

\section{Effect of different stocking densities on economics efficiency:}

The production costs are the main aspects of economical evaluation. The economical evaluation of African catfish Clarias gariepinus in this experiment converted as cultured in earthen ponds (pond/ feddan/ $4000 \mathrm{~m}^{2}$ net water) shown in Table 4 . The costs of culture/ponds was $122,968 \mathrm{~L}$. E. with $\mathrm{T}_{1}, 206,352$ L.E. $\mathrm{T}_{2}$ and 258,152 L. E. at $\mathrm{T}_{3}$. Selling price, L.E/pond was 138,200, 221,520 and 277,280 for $\mathrm{T}_{1}$, $\mathrm{T}_{2}$ and $\mathrm{T}_{3}$, respectively. Net returns L. E. /pond was $15,232,15,168$ and 19,128 for $T_{1}, T_{2}$ and $T_{3}$, respectively. The growth and mortality of Clarias gariepinus cultured at various stocking densities were not initially affected by density but, the overall harvest productions in terms of final weight and size were directly related to the stocking density. As the stocking density was increased, the weight gain was decreased; this depicts an inverse relationship as was observed in similar works by Otubusin and Olaitan (2001).

Table 4. Effect of different stocking density on economic efficiency (Mean \pm S.E)

\begin{tabular}{lccc}
\hline \multicolumn{1}{c}{ Items } & \multicolumn{3}{c}{ Treatments } \\
\cline { 2 - 4 } Costs, L.E/pond & $\mathbf{T}_{\mathbf{1}}$ & $\mathbf{T}_{\mathbf{2}}$ & $\mathbf{T}_{\mathbf{3}}$ \\
Feed & & & $235,752 \pm 266$ \\
Fish & $110,168 \pm 2632$ & $188,752 \pm 6768$ & 14,400 \\
Other costs & 4,800 & 9,600 & 8,000 \\
Total costs, L.E. & 8,000 & 8,000 & $258,152 \pm 266$ \\
Pond biomass, kg & $122,968 \pm 2632$ & $206,352 \pm 6768$ & $27,728 \pm 352$ \\
Selling price, L.E/ pond & $13,820 \pm 220$ & $22,152 \pm 936$ & $277,280 \pm 3520$ \\
Net returns/pond & $138,200 \pm 2200$ & $221,520 \pm 9360$ & $19,128 \pm 3520$ \\
Profit index & $15,232 \pm 432$ & $15,168 \pm 2592$ & $7.41 \pm 1.16$ \\
\hline Price & $12.38 \pm 0.62$ & $7.35 \pm 1.01$ &
\end{tabular}

Price of one $\mathrm{kg}$ selling fish $=10$ L.E., $\quad$ Feed price $/ \mathrm{kg}=4.70$

As shown in Table (4) $\mathrm{T}_{1}$ has an economic advantage, it achieved the lowest costs compared with $\mathrm{T}_{2}$ and $\mathrm{T}_{3}$ so it has the highest profit index when compared with other treatments.

\section{Effect of stocking density on chemical composition}

Results of the chemical composition of whole body fish are shown in Table 5. Crude protein was significantly affected by stocking density $(\mathrm{P} \leq 0.05)$ but other chemical components (dry matter, total 
lipids, ash and gross energy) were insignificantly affected. The lowest protein content in fish body was obtained at high density $\mathrm{T}_{3}(16.2 \%)$, while the highest one was obtained in $\mathrm{T}_{2}(17.10 \%)$.

Table 5. Effect of different stocking density on chemical composition (Mean \pm S.E)

\begin{tabular}{lccccc}
\hline \multirow{2}{*}{ Items } & \multicolumn{4}{c}{ Treatments } & \multirow{2}{*}{ Start } \\
\cline { 2 - 5 } Dray matter (DM) & $\mathbf{T}_{\mathbf{1}}$ & $\mathbf{T}_{\mathbf{2}}$ & $\mathbf{T}_{\mathbf{3}}$ & SED $^{* *}$ & 28.64 \\
Crude protein (CP) & $27.70^{\mathrm{a}} \pm 0.10$ & $27.50^{\mathrm{a}} \pm 0.20$ & $27.70^{\mathrm{a}} \pm 0.20$ & 0.42 & 16.98 \\
Either extract (EE) & $16.55^{\mathrm{ab}} \pm 0.25$ & $17.10^{\mathrm{a}} \pm 0.20$ & $16.20^{\mathrm{b}} \pm 0.06$ & 0.45 & 7.23 \\
Ash & $8.20^{\mathrm{a}} \pm 0.30$ & $7.35^{\mathrm{a}} \pm 0.15$ & $8.00^{\mathrm{a}} \pm 0.20$ & 0.55 & 4.43 \\
Gross energy (GE), $\mathbf{~ k c a l} / \mathbf{g}$ & $2.95^{\mathrm{a}} \pm 0.15$ & $3.05^{\mathrm{a}} \pm 0.15$ & $3.50^{\mathrm{a}} \pm 0.40$ & 0.64 & 1.645 \\
\hline
\end{tabular}

* Averages in the same row having different superscripts are significantly different at $(\mathrm{P} \leq 0.05)$.

** SED, standard error of a difference between two means

\section{The second experiment: \\ Water quality:}

The water quality parameters recorded in this study (Table 6) ranged from $(23-30),(7.90-8.05)$, (5.5-5.8 $\mathrm{mg} / \mathrm{l}),(0-0.4 \mathrm{mg} / \mathrm{L})$ and $(2.3-2.8 \%$ ) for temperature, $\mathrm{pH}$, dissolved oxygen, ammonia and salinity, respectively. The values were within the suitable ranges for catfish culture (Boyd and Litchtkoppler, 1979; Viveen et al., 1985, Auta, 1993 and Adakole, 2000).

Effect of diet's type on growth performance:

The data on growth parameters are presented in Table (7) indicated that final mean body weight, weight gain, average daily gain and SGR were better with $\mathrm{PO}$ and $\mathrm{AF}$ than $\mathrm{FF}$ diet. There were significant differences in these parameters between $\mathrm{PO}$ and FF and also between AF and FF. PO diet recorded an average final weight of $907.5 \mathrm{~g} /$ fish and weight gain of $851 \mathrm{~g} /$ fish, with an average daily gain of $4.05 \mathrm{~g} /$ fish and SGR of average $1.32 \%$. Although there were no significant differences between poultry offal and artificial feed diet, PO diet was the best diet in all treatments in terms of final weight, weight gain, daily gain SGR and survival rate. Survival rate was not significant, both PO and AF diet was better estimated than FF diet $(98.75,98.75$ vs. 97.5\%).

Table 6. Overall mean ( \pm S.E.) of water quality parameters during the second experiment

\begin{tabular}{|c|c|c|c|c|c|c|}
\hline Month & Treatments & $\begin{array}{c}\text { Temp., } \\
{ }^{\circ} \mathrm{C}\end{array}$ & $\begin{array}{c}\mathrm{DO}, \\
\mathrm{mg} / \mathrm{L}\end{array}$ & pH & $\begin{array}{c}\mathrm{NH}_{3}-\mathrm{H}, \\
\mathrm{mg} / \mathrm{L}\end{array}$ & $\begin{array}{c}\text { Salinity, } \\
\% \text { o }\end{array}$ \\
\hline \multirow[t]{3}{*}{ May } & PO & $26 \pm 0.78$ & $5.8 \pm 0.28$ & $8.00 \pm 0.27$ & 0.0 & $2.3 \pm 0.10$ \\
\hline & FF & $26 \pm 0.78$ & $5.8 \pm 0.27$ & $8.00 \pm 0.28$ & 0.0 & $2.3 \pm 0.10$ \\
\hline & $\mathbf{A F}$ & $26 \pm 0.78$ & $5.8 \pm 0.28$ & $8.00 \pm 0.27$ & 0.0 & $2.4 \pm 0.11$ \\
\hline \multirow{3}{*}{ June } & PO & $27 \pm 0.79$ & $5.7 \pm 0.28$ & $7.95 \pm 0.27$ & 0.0 & $2.5 \pm 0.11$ \\
\hline & FF & $27 \pm 0.79$ & $5.8 \pm 0.27$ & $8.00 \pm 0.27$ & 0.0 & $2.3 \pm 0.11$ \\
\hline & $\mathbf{A F}$ & $27 \pm 0.79$ & $5.8 \pm 0.28$ & $8.00 \pm 0.27$ & 0.0 & $2.4 \pm 0.12$ \\
\hline \multirow[t]{3}{*}{ July } & PO & $29 \pm 0.80$ & $5.7 \pm 0.26$ & $7.90 \pm 0.27$ & 0.0 & $2.5 \pm 0.12$ \\
\hline & FF & $29 \pm 0.80$ & $5.7 \pm 0.27$ & $8.05 \pm 0.28$ & $0.2 \pm 0.1$ & $2.4 \pm 0.11$ \\
\hline & $\mathbf{A F}$ & $29 \pm 0.80$ & $5.7 \pm 0.27$ & $8.00 \pm 0.27$ & 0.0 & $2.3 \pm 0.12$ \\
\hline \multirow[t]{3}{*}{ August } & PO & $30 \pm 0.81$ & $5.6 \pm 0.28$ & $7.95 \pm 0.27$ & $0.2 \pm 0.1$ & $2.4 \pm 0.12$ \\
\hline & FF & $30 \pm 0.81$ & $5.8 \pm 0.28$ & $7.95 \pm 0.27$ & $0.2 \pm 0.1$ & $2.5 \pm 0.12$ \\
\hline & $\mathbf{A F}$ & $30 \pm 0.81$ & $5.7 \pm 0.27$ & $7.90 \pm 0.27$ & 0.0 & $2.3 \pm 0.11$ \\
\hline \multirow[t]{3}{*}{ September } & PO & $28 \pm 0.79$ & $5.6 \pm 0.27$ & $7.90 \pm 0.27$ & $0.4 \pm 0.1$ & $2.6 \pm 0.13$ \\
\hline & FF & $28 \pm 0.79$ & $5.6 \pm 0.28$ & $7.95 \pm 0.27$ & $0.4 \pm 0.1$ & $2.5 \pm 0.12$ \\
\hline & $\mathbf{A F}$ & $28 \pm 0.78$ & $5.7 \pm 0.28$ & $8.00 \pm 0.28$ & $0.2 \pm 0.1$ & $2.6 \pm 0.13$ \\
\hline \multirow[t]{3}{*}{ October } & PO & $26 \pm 0.77$ & $5.7 \pm 0.27$ & $7.95 \pm 0.27$ & $0.4 \pm 0.1$ & $2.5 \pm 0.12$ \\
\hline & FF & $26 \pm 0.77$ & $5.7 \pm 0.28$ & $8.00 \pm 0.27$ & $0.4 \pm 0.1$ & $2.5 \pm 0.12$ \\
\hline & $\mathbf{A F}$ & $26 \pm 0.78$ & $5.6 \pm 0.27$ & $8.00 \pm 0.27$ & $0.2 \pm 0.1$ & $2.5 \pm 0.13$ \\
\hline \multirow[t]{3}{*}{ November } & PO & $25 \pm 0.76$ & $5.5 \pm 0.28$ & $7.90 \pm 0.27$ & $0.4 \pm 0.1$ & $2.8 \pm 0.13$ \\
\hline & FF & $25 \pm 0.76$ & $5.6 \pm 0.27$ & $8.05 \pm 0.29$ & $0.4 \pm 0.1$ & $2.7 \pm 0.13$ \\
\hline & $\mathbf{A F}$ & $25 \pm 0.77$ & $5.7 \pm 0.27$ & $7.95 \pm 0.27$ & $0.2 \pm 0.1$ & $2.8 \pm 0.13$ \\
\hline \multirow[t]{3}{*}{ December } & PO & $23 \pm 0.76$ & $5.5 \pm 0.27$ & $8.00 \pm 0.27$ & $0.4 \pm 0.1$ & $2.5 \pm 0.12$ \\
\hline & FF & $23 \pm 0.75$ & $5.6 \pm 0.27$ & $8.00 \pm 0.27$ & $0.4 \pm 0.1$ & $2.5 \pm 0.12$ \\
\hline & $\mathbf{A F}$ & $23 \pm 0.76$ & $5.5 \pm 0.27$ & $7.90 \pm 0.27$ & $0.2 \pm 0.1$ & $2.6 \pm 0.12$ \\
\hline
\end{tabular}

Results presented in Table (7) showed that the best growth performance was with PO diet. This performance was superior to those of AF and FF fed fish possibly due to Poultry offal as a high quality animal protein and Poultry offal contained reasonable amount of proximate components, essential amino acids and important minerals according to Hossain et al. (1989) and the crude protein of the chicken offal is slightly higher than that of local fish meal. The fat content of the chicken offal was higher than that of 
local fish meal. Faturoti (2000) reported that local chicken offal (cooked and dried) contained 61.6\% crude protein (CP), $16.5 \%$ crude lipid, $3.5 \%$ crude fiber, $9.0 \%$ ash and $8.3 \%$ moisture.

Table 7. Effect of diet's type on growth performance (Mean \pm S.E)

\begin{tabular}{lcccc}
\hline \multirow{2}{*}{ Items } & \multicolumn{3}{c}{ Diet's type } & \multirow{2}{*}{ SED ** } \\
\cline { 2 - 4 } & PO & $\mathbf{A F}$ & $\mathbf{F F}$ & 5.79 \\
Initial mean body weight, $\mathbf{g}$ & $56.5^{\mathrm{a}} \pm 1.5$ & $56.5^{\mathrm{a}} \pm 3.5$ & $56.5^{\mathrm{a}} \pm 1.5$ & 59.69 \\
Final mean body weight, $\mathbf{g}$ & $907.5^{\mathrm{a}} \pm 32.5$ & $855^{\mathrm{a}} \pm 25.0$ & $730^{\mathrm{b}} \pm 10.0$ & 54.69 \\
Weight gain, g & $851^{\mathrm{a}} \pm 31.0$ & $798.5^{\mathrm{a}} \pm 21.5$ & $673.5^{\mathrm{b}} \pm 8.5$ & 54.6 \\
Average daily gain, g & $4.05^{\mathrm{a}} \pm 0.15$ & $3.80^{\mathrm{a}} \pm 0.10$ & $3.21^{\mathrm{b}} \pm 0.04$ & 0.29 \\
SGR, \% /day & $1.32^{\mathrm{a}} \pm 0.004$ & $1.29^{\mathrm{a}} \pm 0.015$ & $1.22^{\mathrm{b}} \pm 0.006$ & 0.03 \\
Survival rate\% & $98.75^{\mathrm{a}} \pm 1.25$ & $98.75^{\mathrm{a}} \pm 1.25$ & $97.50^{\mathrm{a}} \pm 0.10$ & 5.00 \\
\hline
\end{tabular}

* Average in the same row having different superscripts significantly different at $(\mathrm{P} \leq 0.05)$.

** SED, standard error of a difference between two means

In addition, Nengas et al. (1999) reported that PBM can be used without amino acid supplementation to replace $50 \%$ of the FM in diets for gilthead seabream. Gomaah (2006) stated that PBPM can be a replacement of fish meal protein at $35 \%$ in African catfish diets. The positive effect of the diets based on PBM is because of the increase in n-6 level in the muscle of fish. It is thought, as an important factor, that affects the nutritional quality of fish muscle. Therefore, future investigation should be focused on using PBM as a replacement of fish meal with supplementation of high amount of amino acids to improve the growth performance and acceptability fatty acid profiles especially n- Poultry 3 for fish according to (Gümüş and Aydin, 2013).

\section{Effect of diet's type on feed utilization of African catfish:}

As shown in Table (8) there were significant differences in feed intake, FCR, PER, PPV and EPV\%. The highest feed intake and FCR values were recorded with PO (4850 and 5.69). These are due to that the diets were offered as wet shape. There were significant differences among studied diet types where those fed with the AF had the highest PER, PPV, EER and EPV\%, but those that were fed with PO had the lowest estimates $(2.01,34.65,0.12$ and 0.19 vs. $0.64,10.61,0.04$ and 0.07 , respectively).

Table 8. Effect of diet's type on feed utilization of African catfish (Mean \pm S.E)

\begin{tabular}{lcccc}
\hline Items & \multicolumn{3}{c}{ Diet's type } & \multirow{2}{*}{ SED** } \\
\cline { 2 - 4 } & PO & AF & FF & \\
\hline Feed intake, g/fish & $4850^{\mathrm{a}} \pm 350$ & $1460^{\mathrm{c}} \pm 80$ & $2875^{\mathrm{b}} \pm 125$ & 537.63 \\
FCR & $5.69^{\mathrm{a}} \pm 0.20$ & $1.83^{\mathrm{c}} \pm 0.05$ & $4.27^{\mathrm{b}} \pm 0.13$ & 0.35 \\
PER & $0.64^{\mathrm{c}} \pm 0.02$ & $2.01^{\mathrm{a}} \pm 0.05$ & $0.86^{\mathrm{b}} \pm 0.03$ & 0.09 \\
PPV\% & $10.61^{\mathrm{c}} \pm 0.24$ & $34.65^{\mathrm{a}} \pm 1.07$ & $14.05^{\mathrm{b}} \pm 0.53$ & 1.73 \\
EER & $0.04^{\mathrm{c}} \pm 0.001$ & $0.12^{\mathrm{a}} \pm 0.003$ & $0.05^{\mathrm{b}} \pm 0.001$ & 0.01 \\
EPV\% & $0.07^{\mathrm{c}} \pm 0.002$ & $0.19^{\mathrm{a}} \pm 0.006$ & $0.09^{\mathrm{b}} \pm 0.003$ & 0.03 \\
\hline
\end{tabular}

* Average in the same row having different superscripts significantly different at $(\mathrm{P} \leq 0.05)$.

** SED, standard error of a difference between two means

These results indicated that, feed intake, g/ fish was higher with poultry offal diet than factory by product and artificial feed may be due to this fish is an omnivorous scavenger (Teugel et al., 1990) and poultry offal diet (PO) as animal protein ingredients is good sources of amino acids with high protein content, total digestible dry matter and energy similar to fish meal according to Bureau et al. (2000). FCR, PER, PPV, EER and EPV were the best with those fed with the AF because artificial feeds is scientifically formulated, adequately supplied and artificial diets may be either complete or supplemental. Complete diets supply all the ingredients i.e. (protein, carbohydrates, fats, vitamins, and minerals) necessary for the optimal growth and health of the fish. In contrast, Pfeffer et al. (1995) found that increasing the dietary proportion of poultry slaughter by-products decreased protein and lipid digestibility in rainbow trout, and may be due to limiting amino acids (histidine, methionine + cystine, lysine and phenylalanine) in poultry offal content according to Tacon and Jackson (1985), feather, connective tissue and skin contents which are considered to be difficult for fish to digest (Hasan and Amin 1997 and Hardy, 2000). These results are in agreement with Tabinda and Butt (2012) who reported that chicken intestine is rich in protein but unfortunately not being utilized as protein source in fish feed.

\section{Effect of types of diets on profitability of African catfish cultured in earthen ponds:}

The production costs are the main aspects of economical evaluation. The economical evaluation of Clarias gariepinus cultured in earthen ponds under 
effect of the three diets showed that the costs of culturing/ ponds was 89,600 L.E. with first treatment (PO), 122,592 L.E. (AF) and 81,800 L. E. with (FF). Selling price, L.E/ pond were 143,450, 135,140 and
113,880 with PO, AF and FF diet respectively. Net returns L.E. /pond was 53,850, 12,548 and 32,080 with PO, AF and FF diet, respectively (Table 9).

Table 9. Effect of diet's type on economic efficiency of African catfish (Mean \pm S.E)

\begin{tabular}{lccc}
\hline \multirow{2}{*}{ Items } & \multicolumn{3}{c}{ Diet type } \\
\cline { 2 - 4 } Costs, L.E/pond & PO & AF & FF \\
Feed & $58,200 \pm 4200$ & $109,792 \pm 6016$ & $69,000 \pm 3000$ \\
Fish & 4,800 & 4,800 & 4,800 \\
Other costs & 26,600 & 8,000 & 8,000 \\
Total costs, L.E. & $89,600 \pm 4200$ & $122,592 \pm 6016$ & $81,800 \pm 3000$ \\
Pond biomass, kg & $14,345 \pm 695$ & $13,514 \pm 566$ & $11,388 \pm 156$ \\
Selling price, L.E/ pond & $143,450 \pm 6950$ & $135,140 \pm 5660$ & $113,880 \pm 1560$ \\
Net returns/pond & $53,850 \pm 2750$ & $12,548 \pm 356$ & $32,080 \pm 1440$ \\
Profit index & $60.10 \pm 0.25$ & $10.24 \pm 0.79$ & $39.22 \pm 3.20$ \\
\hline Pric
\end{tabular}

Price of one $\mathrm{kg}$ selling fish $=10$ L.E

Price of $\mathrm{kg}$ feed $=1,4.70$ and 1.5 L.E from poultry offal, artificial feed and factory by product, respectively.

Effect of diet's type on chemical composition of African catfish:

Body chemical composition and energy content of catfish at both beginning and end of the experiment are shown in Table (10). The results showed that significant differences $(\mathrm{P} \leq 0.05)$ were obtained in $\mathrm{CP}, \mathrm{EE}$, ash and GE of body composition at the end of the experimental period, however DM had no significant difference. The highest protein and ash content were shown for those fed the AF and had the lowest EE and GE (6.75 and 1.610), however those fed the FF diet had the lowest CP and ash\% $(16.40$ and $3.05 \%)$ and the highest EE and GE (8.40 and 1.718).

Table 10. Effect of diet's type on chemical composition of African catfish (Mean \pm S.E)

\begin{tabular}{lccccc}
\hline \multirow{2}{*}{ Items } & \multicolumn{4}{c}{ Diet's type } & \multirow{2}{*}{ Start } \\
\cline { 2 - 5 } & $\mathbf{P O}$ & $\mathbf{A F}$ & $\mathbf{F F}$ & SED $^{* *}$ & \\
\hline Dray matter (DM) & $27.73^{\mathrm{a}} \pm 0.13$ & $27.80^{\mathrm{a}} \pm 0.20$ & $27.85^{\mathrm{a}} 0.05$ & 0.34 & 28.93 \\
Crude protein (CP) & $16.50^{\mathrm{b}} \pm 0.20$ & $17.25^{\mathrm{a}} \pm 0.05$ & $16.40^{\mathrm{b}} \pm 0.10$ & 0.32 & 16.48 \\
Either extract (EE) & $8.00^{\mathrm{a}} \pm 0.20$ & $6.75^{\mathrm{b}} \pm 0.05$ & $8.40^{\mathrm{a}} \pm 0.10$ & 0.32 & 7.53 \\
Ash & $3.23^{\mathrm{b}} \pm 0.13$ & $3.80^{\mathrm{a}} \pm 0.10$ & $3.05^{\mathrm{b}} \pm 0.15$ & 0.31 & 4.92 \\
Gross energy (GE), kcal/g & $1.686^{\mathrm{a}} \pm 0.007$ & $1.610^{\mathrm{b}} \pm 0.007$ & $1.718^{\mathrm{a}} \pm 0.015$ & 0.03 & 1.64 \\
\hline
\end{tabular}

* Average in the same row having different superscripts significantly different at $(\mathrm{P} \leq 0.05)$.

** SED, standard error of a difference between two means

\section{CONCLUSION}

From the results obtained, it can be concluded that catfish can be cultured under high stocking density $\left(\mathrm{T}_{3}\right)$ without causing any problems in semiintensive at earthen ponds system, and using nontraditional diets of poultry slaughter (PO) and wastes of food factory (FF) could be used to reduce the costs of production

\section{REFERENCE}

Abdel-Warith, A., S.J. Davies and P. Russell, 2001. Inclusion of a commercial poultry by-product meal as a protein replacement of fish meal in practical diets for the African catfish Clarias gariepinus. Aquacult. Res., 32: 296-306.

Abu O.M.G., L.O. Sanni, E.S. Erondu, and O.A. Akinrotimi, 2010. Economic viability of replacing maize with whole cassava root meal in the diet of Hybrid Cat-fish. Agric. J. 1:1-5.

Adakole, J. A., 2000. The effects of diuretic, agricultural and industrial effluents on the water quality and Biota of Bindare stream, Zaria-
Nigeria. Unpublished Ph.D Thesis. Ahmadu Bello University Zaria Nigeria $256 \mathrm{pp}$.

Aksungur, N., M. Aksungur, B. Akbulut and I. Kutlu, 2007. Effects of stocking density on growth performance, survival and food conversion ratio of Turbot (Psetta maxima) in the net cages on the southeastern coast of the black sea J. Fish. Aquat. Sci. 7: 147-152.

Almazán-Rueda, P., 2004. Towards assessment of welfare in African catfish, Clarias gariepinus: the first step. PhD thesis, Wageningen University, The Netherlands. $151 \mathrm{pp}$.

Amisah, S., M.A. Oteng and J.K. Ofori, 2009. Growth performance of the African catfish (Clarias gariepinus) fed varying inclusion levels of Leucanena leaf meal. J. Appl. Sci. Environ. Manag. 13: 21-26.

AOAC (Association of Official Analytical Chemists). 2000. Official methods of analysis, 17 th edition. Association of Official Analytical Chemists, Arlington, Virginia, USA. 
Auta, J., 1993. Water Quality Management in Fish Ponds. Proceedings of National Workshop on Fisheries Extension Delivery. 2 P.

Baras, E. and M. Jobling, 2002. Dynamics of intracohort cannibalism in cultured fish Aquacult. Res., 33: 461-479.

Begout-Anras, M.L. and J.P. Lagardère, 2004. Domestication et comportement chez les poisons téléostéens. INRA Prod. Anim. 17: 211-215.

Bjoernsson, B., 1994. Effects of stocking density on growth rate of Halibut Hippoglossus hippoglossus L. reared in large circular tanks for three years. Aquaculture, 123: 259-270.

Boujard, T., L. Labbé and B. Aupérin, 2002. Feeding behaviour, energy expenditure and growth of rainbow in relation to stocking density and food accessibility. Aquaculture Research 33: 12331242.

Boyd C.E., and F. Litchtkoppler, 1979. Water quality management in pond fish culture. International Centre for Aquaculture. Agric. Expt. Station, Auburn Univ. Auburn, Alabama. Research and Dev. Ser. No. 22. Projects: AID/DSAN-G 0039, p. 30 .

Bureau, D. P., A.M. Harris, D.J. Bevan, L. A. Simmons, P.A. Azevedo and C.Y. Cho, 2000. Feather meals and meat and bone meals from different origins as protein sources in rainbow trout (Oncorhynchus mykiss) diets. Aquaculture, 181: 281-291.

Charo-Karisa H., H. Komen, S. Reynolds, M.A. Rezk, R.W. Ponzoni and H. Bovenhuis, 2006. Genetic and environmental factors affecting growth of Nile tilapia (Oreochromis niloticus) juveniles: Modeling spatial correlations between hapas. Aquaculture 255:586-596.

Coulibaly A., I.N. Ouattara, T. Koné, V. N'Douba, J. Snoeks, G. Gooré Bi. and E.P. Kouamelan, 2007. First results of floating cage culture of the African catfish Heterobranchus longifilis Valenciennes, 1840: Effect of stocking density on survival and growth rates. Aquaculture 263: 61-67.

Cruz, E.M., and M. Ridha, 1989. Preliminary study on the production of tilapia, Oreochromis spilurus (Günther), cultured in seawater cages. Aquac. Fish. Manage. 20: 381-388.

Dada A.A. and C. Wonah, 2003. Production of exotic C. gariepinus at varying stocking density in outdoor ponds. Journal of aquatic science 18: 2124.

Dasuki, A., J. Auta, and S.J. Oniye, 2013. Effect of stocking density on production of Clarias gariepinus (tuegels) in floating bamboo cages at Kubanni reservior, Zaria, Nigeria Bayero Journal of Pure and Applied Sciences, 6: 112-117.

Diana, J.S., and A.W. Fast, 1989. The effects of water exchange rate and density on yield of the walking catfish, Clarias fuscus. Aquaculture 78: 267-276.

Duncan, D. B., 1955. Multiple range and multiple F tests. Biometrics 11:1-42.
Edward, A., B.M.B. Ladu and A. Elihu, 2010. Growth, survival and production economics of Clarias gariepinus fingerlings at different stocking densities in concrete tanks. African Journal of General Agriculture 1595-6984.

Effiong B.N., A. Sanni and J.O. Fakunle, 2009. Effect of partial replacement of fishmeal with duckweed (Lemna paucicostata) meal on the growth performance of Heterobranchus longifilis fingerlings. Report Opin. 1(3):76-81.

Ellis, T., B. North, A.P. Scott, N.R. Bromage, M. Porter and D. Gadd, 2002. The relationships between stocking density and welfare in farmed rainbow trout. Journal of Fish Biology, 61: 493531.

El-Sayed A., 2002. Effects of stocking density and feeding levels on growth and feed efficiency of Nile tilapia (Oreochromis niloticus L.) fry. Aquac Res 33: 621-626

Engle, C. R., and D. Valderrama, 2001. Effect of stocking density on production characteristics, coasts, and risk of producing fingerlings channel catfish. North American Journal of Aquaculture 63: 201-207.

Ewa-Oboho I., and U.K. Enyenihi, 1999. Aquaculture implications of growth and variation in the African catfish: Heterobranchus longifilis (Val.) reared under controlled conditions. Journal of Applied Ichthyology 15: 111-115.

Fasakin, E. A., R. D. Serwata and S. J. Davies, 2005. Comparative utilization of rendered animal derived products with or without composite mixture of soybean meal in hybrid tilapia (Oreochromis niloticus $\times$ Oreochromis mossambicus) diets. Aquaculture, 249: 329-338.

Faturoti, E.O., 2000. Beneath the Ripples and Sustainable fish Production. Inaugural Lecture, University of Ibadan, Ibadan. pp. 54.

GAFRD 2012. General authority for fish resources development. Fishery statistic. Egyptian Ministry of Agriculture.

Gomaah, S.A.A., 2006. Partial replacement of fish meal protein with poultry by-product meal (PBPM) protein in practical diets of African catfish (Clarias gariepinus) reared in earthen ponds: Growth performance of fish. The $2^{\text {nd }}$ international scientific congress for environment "recent environmental problems and social sharement" 28-30 March, South Valley University.

Gümüs, E., and A. Aydin, 2013. Effect of Poultry By-Product Meal on Growth Performance and Fatty Acid Composition of Carp (Cyprinus carpio) Fry. Turkish Journal of Fisheries and Aquatic Sciences 13: 827-834.

Hardy, R.W., 2000. New developments in aquatic feed ingredients, and potential of enzyme supplements. L.E. Cruz-Suarez, D. Ricque-Marie, M. Tapia- Salazar, M.A. Olvera-Novoa, and R. Civera- Cerecedo, (Eds.), Avaces en Nutricion Acuicola V. Memorias del V Simposium 
Internacional de Nutricion Acuicola, Mérida, Yucatan, Mexico: 216-226.

Hasan, M.R. and M.R. Amin, 1997. Effect of processing techniques on the nutritional quality of poultry offal meal. Bangladesh Journal of Fisheries, 20: 139-144.

Haylor, G. S., 1992. Controlled hatchery production of Clarias gariepinus (Burchell 1822): growth and survival of larvae at high stocking density. Aquacult. Fish. Manage. 23: 303-314.

Hecht, T. and A.G. Pienaar, 1993. A review of cannibalism and its implications in fish larvae culture. Journal of the World Aquaculture Society 24: 246-261.

Hecht, T. and W. Uys, 1997. Effect of density on the feeding and aggressive behaviour in juvenile African catfish, Clarias gariepinus. S. Afr. J. Sci. 93: 537-541.

Hecht, T., L. Oellermann and L. Verheust, 1996. Perspectives on clariid catfish culture in Africa. In: Legendre, M., Proteau, J.-P. (Eds.), The Biology and Culture of Catfishes. Aquat. Living Resour., 9: 197-206. Hors serie.

Hecht, T., P. Sorgeloos, J. Verreth and F. Ollevier, 1997. Guide to the biology and culture of the African catfish. Website project funded by the Flemish Ministry of Education, the University of Ghent, Rhodes University and Liberty Life Educational Foundation Johannesburg. http//cdserver2.ru.ac.za/cd/catfish..

Hossain M. D., S. M. Bulbul and M. A. R. Howlider, 1989. The composition of some Unconventional feeds. Poult. Adv., 22 : 37-40.

Jamabo, N.A. and R.I. Keremah, 2009. Effects of Stocking Density on the Growth and Survival of the Fingerlings of Clarias gariepinus (Burchell, 1822). Journal of Fisheries International. 4: 5557.

Lambert, Y. and J.D. Dutil, 2001. Food intake and growth of adult Atlantic cod (Gadus morhua L.) reared under different conditions of stocking density, feeding frequency and size-grading. Aquaculture 192: 233-247

Leatherland, J. F. and C.Y. Cho, 1985. Effect of rearing density on thyroid and inter- renal gland activity and plasma and hepatic metabolite levels in rainbow trout, Salmo gairdneri Richardson. Journal of Fish Biology, 27: 583-592.

Lochmann, R.T. and H. Phillips, 1995. Comparison of rice bran oil, poultry fat and cod liver oil as supplemental lipids in feeds for Channel catfish and golden shiner. Journal of Appl. Aquaculture 5: 47-56.

Millamena, O.M., 2002. Replacement of fish meal by animal by-product meals in a practical diet for grow-out culture of grouper Epinephelus coioides. Aquaculture, 204: 75 -84.

Muzinic, L.A., K.R. Thompson, L.S. Metts, S. Dasgupta and C.D. Webster, 2006. Use of turkey meal as partial and total replacement of fish meal in practical diets for sunshine bass (Morone chrysops $\times$ Morone saxatilis) grown in tanks. Aquacult. Nutr., 12: 71-81.

Nengas, I., M.N. Alexis and S.J. Davies, 1999. High inclusion levels of poultry meals and related byproducts in diets for gilthead seabream (Sparus aurata L.). Aquaculture, 179: 13-23.

Osofero, S. A., Otubusin, S.O. and Daramola, J. A., 2007. Effect of Stocking density on Tilapia (Oreochromis niloticus, Linnaeus 1757) growth and survival in Bamboo- net cages trial. In: Journal of fisheries international 2: $182-185$.

Otubusin, S.O. and O.O. Olaitan, 2001. The production of cat fish (Clarias gariepinus) in floating bamboo net-cage system in Nigeria. ASSET Series A, $1: 77-82$.

Papoutsoglou S.E., G. Tziha, X. Vrettos and A. Athanasiou, 1998. Effects of stocking density on behavior and growth rate of European sea bass (Dicentrarchus labrax) juveniles reared in a closed circulated system Aquac Eng 18:135-144

Pfeffer, E., S. KInzinger and M. Rodehutscord, 1995. Influence of the proportion of poultry slaughter byproducts and untreated or hydrothermically treated legume seeds in diets for rainbow trout, Onchorhynchus mykiss (Walbaum), on apparent digestibilities of their energy and organic compounds. Aquaculture Nutrition 1:111-117.

Rad, F., G.I. Kurt and A.S. Bozaoủlu, 2003. Effects of spatially localized and dispersed patterns of feed distribution on the growth, size dispersion and feed conversion ratio of the African Catfish (Clarias gariepinus). Turk. J. Vet. Anim. Sci. 28: 851-856.

Rahman, M. A., M A. Mazid, M. R. Rahman, M. N. Khan, M. A. Hossain and M. G. Hussain, 2005. Effect of stocking density on survival and growth of critically endangered mashseer, Tor putitora (Hamilton), in nursery ponds. Aquaculture 249: 275-284.

Rawles, S. D., M. Riche, T.G. Gaylord, J. Webb, D. W. Freeman and M. Davis, 2006. Evaluation of poultry by-product meal in commercial diets for hybrid striped bass (Morone chrysops $\times M$. saxatilis) in recirculated tank production. Aquaculture, 259: 377-389.

Rowland S., G. Allan, M. Hollis and T. Pontifex, 2004. Production of Silver perch (Bidyanus bidyanus) fingerlings at three stocking densities in cages and tanks. Aquaculture, 229: 193-202.

Soltan, M.A. and A.A. Tharwat, 2006. Use of fish silage for partial or complete replacement of fishmeal in diets of Nile tilapia (Oreochromis niloticus) and African catfish (Clarias gariepinus).Egypt. J. Nutr. Feeds 9: 299-314.

SPSS, 2007. Statistical Package For Social Science (for Windows). Release 16 Copyright (C), SPSS Inc., Chicago, USA.

Sugunan, W. and P. Katiha, 2004. Impact of stocking density on yield in small reservoirs in AndraPradesh, India. Fisheries Management and Ecology11: 193-202. 
Tabinda, A. B. and A. Butt, 2012. Replacement of Fish Meal With Poultry By-Product Meal (Chicken Intestine) as a Protein Source in Grass Carp Fry Diet. Pakistan J. Zool., vol. 44: 13731381

Tacon, A.G.J. and A.J. Jackson, 1985. Utilization of conventional and unconventional protein sources in practical fish feeds. In: Nutrition and feeding of fish (eds. C. B. Cowey, A. M. Mackie and J. G. Bell), Academic Press. London. UK. pp. 119145 .

Teugel, G. G., B. Denayer and M. Legendre, 1990. Zoological Journal of the Lannean Society 98:237-257.

Viveen, W.J.A.R., C.J.J. Richter, P.G.W.J. Van Oordt, J.A.L. Janseen and E.A. Huisman, 1985. Practical manual for the culture of the African catfish (Clarias gariepinus). The Netherlands Ministry for Development Corporation, Section for Research and Technology, The Hague, The Netherlands, $128 \mathrm{pp}$.

Wei, Z., M. Kangsen, Z. Baigang, W. Fuzhen and Y. $\mathrm{Yu}, 2004$. A study on the meat and bone meal and poultry by-product meal as protein substitutes of fish meal in practical diets for Litopenaeus vannamei Juveniles. J. Ocean Univ. China (Ocean. Coast. Sea Res.), 3: 157-160.

Wei, Z., M. Kangsen, Z. Baigang, H. Yangjiang and Y. Yu, 2006. A study on the meat and bone meal or poultry by-product meal as protein substitutes of fishmeal in concentrated diets for Paralichthys olivaceus. J. Ocean Univ. China (Ocean. Coast. Sea Res.), 5: 63-66.

\section{تأثير كثافة التخزين ونـوع العليقة على مظاهر النمو والكفـاءة الإقتصـادية للقرموط الافريقى تحت نظـام التربية شبه المكثفة

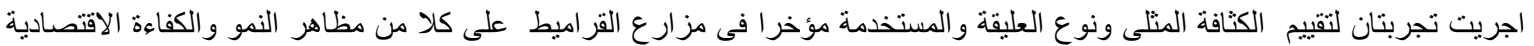

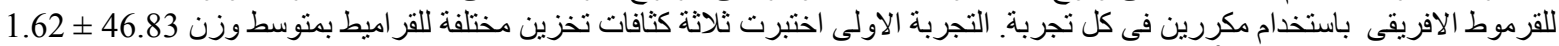

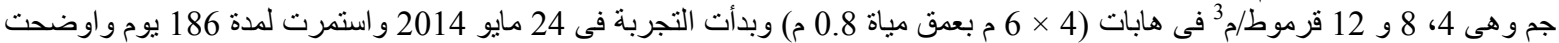

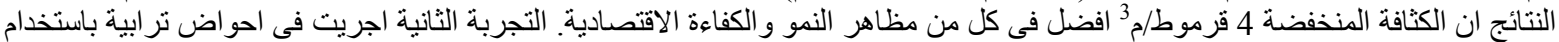

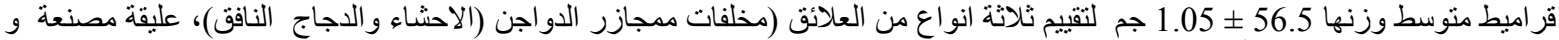

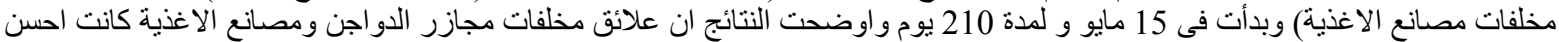

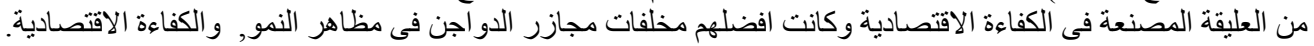

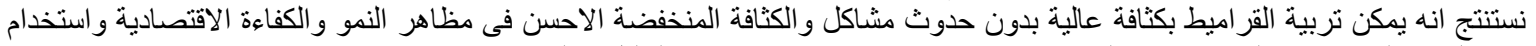
العلائق الغير تقليدية من مخلفات مجازر الدواجن ومصانع الاغذية يمكن استخدامها لتقليل تكاليف الانتاج 